\title{
Damage levels caused by Capulinia linarosae Kondo \& Gullan (Hemiptera: Eriococcidae) on guava crops under two agronomic management practices in the south of Lake Maracaibo, Venezuela
}

\section{Niveles de daño causados por Capulinia linarosae Kondo \& Gullan (Hemiptera: Eriococcidae) en cultivos de guayaba bajo dos prácticas de manejo agronómico en el sur del lago de Maracaibo, Venezuela}
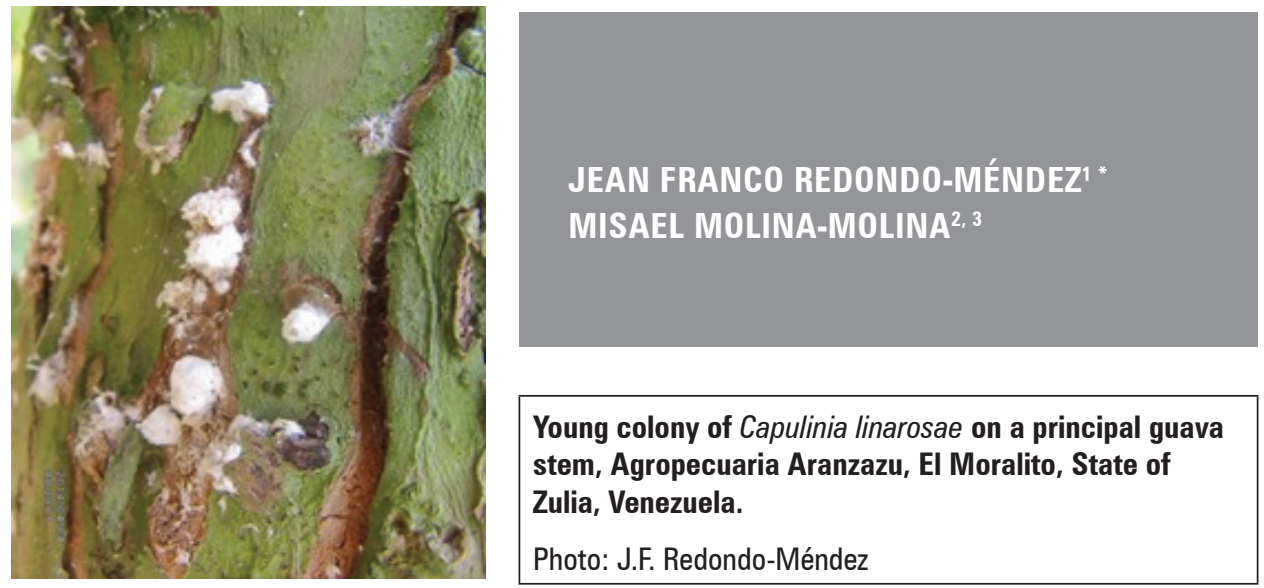

Young colony of Capulinia linarosae on a principal guava stem, Agropecuaria Aranzazu, El Moralito, State of Zulia, Venezuela.

Photo: J.F. Redondo-Méndez

\begin{abstract}
The objective of the present study was to test the hypothesis of no difference in the level of damage caused by the guava cottony scale Capulinia linarosae (Hemiptera: Eriococcidae) in two guava crops under different agronomic management practices; a crop with organic management practices $\left(\mathrm{PU}_{\mathrm{A}}\right)$ was compared with another subjected to chemical methods $\left(\mathrm{PU}_{\mathrm{B}}\right)$. Forty plants on each farm were selected randomly to estimate damage on the stems, branches, leaves, and fruits. The levels of damage were statistically different $(P<0.0001)$ between the methods for the stems and branches but not for the leaves or fruits $(P>0.05)$. It was concluded that the magnitude of damage was greater in the crop under chemical control and that agronomic management was a critical factor. Excess insecticides and incorrect pruning applications cause damage to plant bark and favor insect proliferation. While the use of a sulfur-calcium broth in $\mathrm{PU}_{\mathrm{A}}$ regulated $\mathrm{pH}$, it favored the

Universidad Nacional Experimental Sur del Lago, Programa Ingeniería de la Producción Agropecuaria, Santa Barbara de Zulia (Venezuela).

2 Universidad Nacional Experimental Sur del Lago, Grupo de Investigaciones en Acuicultura y Zoología Aplicada, Programa Ingeniería de Alimentos, Santa Barbara de Zulia (Venezuela). ORCID Molina-Molina, M.: 0000-0003-2495-7600 Corresponding author.molinam@unesur.edu.ve

* Article based on the thesis "Incidencia de la mota blanca (Capulinia sp.) del guayabo en dos unidades de producción del municipio Colón, Parroquia El Moralito que difieren en el manejo agronómico".
\end{abstract}


effect of other products and promoted the growth of green algae, which covered bark crevices and inhibited cottony scale establishment. The excessive use of agrochemicals for weed control in $\mathrm{PU}_{\mathrm{B}}$ caused soil nudity and killed natural enemies, whereas, in $\mathrm{PU}_{\mathrm{A}}$, the grass layer was clipped at $20 \mathrm{~cm}$ from the soil, maintaining moisture and creating a favorable habitat for natural enemies.

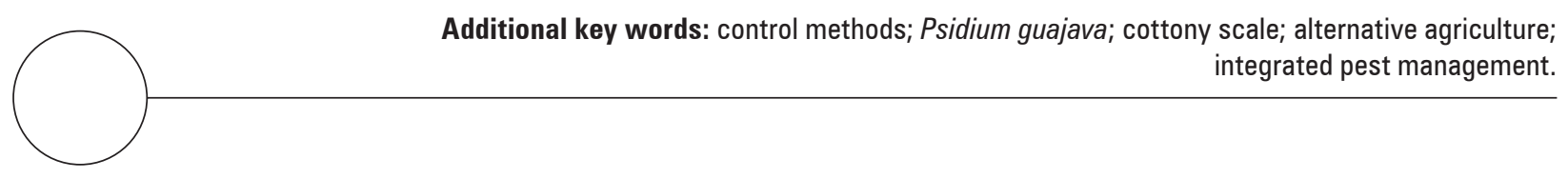

\section{RESUMEN}

El objetivo del estudio fue someter a prueba la hipótesis de que no hay diferencias en el nivel del daño causado por Capulinia linarosae (Hemiptera: Eriococcidae) en dos cultivos de guayaba sometidos a prácticas de manejos agronómicos diferentes: se comparó un cultivo cuyas prácticas de manejo tienden a orgánicas $\left(\mathrm{UP}_{\mathrm{A}}\right)$ con otro sometido a métodos químicos $\left(\mathrm{UP}_{\mathrm{B}}\right)$. En cada cultivo se seleccionaron 40 plantas al azar para estimar el daño en tallos, ramas, hojas y frutos. Se encontraron diferencias estadísticamente significativas $(P<0,0001)$ entre los dos métodos de control para tallos y ramas, pero no para hojas ni frutos $(P>0,05)$. Se concluye que la magnitud del daño es mayor en el cultivo sometido a control químico y que el manejo agronómico es un factor crítico. El exceso de insecticidas y la aplicación incorrecta de podas en la $\mathrm{UP}_{\mathrm{B}}$ dañan la corteza de las plantas y favorecen la proliferación del insecto. Mientras que el uso de caldo Sulfo-cálcico en la $\mathrm{UP}_{\mathrm{A}}$ regula el $\mathrm{pH}$, favorece el efecto de otros productos y promueve el establecimiento de algas verdes que cubren las grietas dificultando el establecimiento del insecto. El exceso de agroquímicos para el control de malezas en $\mathrm{UP}_{\mathrm{B}}$ deja el suelo desnudo, matando sus enemigos naturales, mientras que en la $\mathrm{UP}_{\mathrm{A}}$ se corta el estrato herbáceo a unos $20 \mathrm{~cm}$ del suelo, manteniendo su humedad y creando un hábitat favorable a los controladores biológicos.

Palabras clave adicionales: métodos de control; Psidium guajava; mota blanca; agricultura alternativa; manejo integrado de plagas.

Received for publication: 14-01-2019 Accepted for publication: 30-03-2020

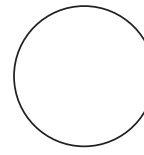

The guava (Psidium guajava L.) is a tree in the Myrtaceae family that originated in the tropical Americas although it is now distributed throughout the planet. Global production of guava fruits is close to $31 \mathrm{mil}-$ lion tons, with India, China, and Thailand contributing more than $75 \%$ of this total. Mexico produces $5 \%$, Brazil produces almost $4 \%$, and the rest is provided by other countries, including Indonesia, Philippines, Bangladesh, and Nigeria, among others (Mendes et al., 2017; Reddy, 2018).

The production of guava in Venezuela began in the '80s and quickly became one of the most important fruit crops. The varieties present in the country are mainly: 'Criolla Roja', 'San Miguel' and 'Rio Chiquito' (Aular and Casares, 2011). By 1992, there were about 4,000 ha of crop production that were almost entirely located on the Maracaibo plain (Cermeli and Geraud-Pouey, 1997). By 1996, the cultivated area was 3,000 ha, reaching 3,500 ha in 2008 . The average annual yield has been between 15 and $20 \mathrm{t} \mathrm{ha}^{-1}$, and the total national production has varied between 50,000 and 60,000 t (Quijada and Matheus, 1997).

Since its appearance in Venezuela at the beginning of 1993, the guava cottony scale (Capulinia linarosae Kondo \& Gullan, 2016, Figs. 1A and 1B), has caused severe damage (Geraud-Pouey et al., 2001a; Camacho et al., 2002; León et al., 2014; Kondo et al., 2016) and, more recently in Colombia (Kondo et al., 2016; Ramos Portilla, 2018), has become the principal pest in this crop. The damage is caused mainly by nymphs and adult females that feed on the sap they extract with their sucking mouth apparatus, which is introduced 
through the cortex (Cermeli and Geraud-Pouey, 1997). Adult females lay about 300 eggs, and populations can multiply more than 150 times per generation $(43.2 \mathrm{~d})$. This reproductive potential explains the occurrence of population outbreaks observed in the field. The rapidly growing colonies cover trees that, according to Chirinos et al. (2004), in extreme cases appear to be covered by snow.

Colonies usually begin development on the most shaded stem-parts and branches, covering it completely (Chirinos et al., 2004). As the colony grows, a necrotic patch of internal tissues occurs, causing the bark to crack, forming a kind of canker (Chirinos et al., 2004). The necrotic areas impede the normal circulation of sap, producing leave-yellowing and later a generalized withering (Chirinos et al., 2004). As a result, the plant looks like it has been burned (Chirinos et al., 2004).

In the south of Lake Maracaibo (SLM), problems generated by C. linarosae are considerable. Large crop areas are affected, and, in some cases, attacks have caused mortality in most of the plants. Several alternatives have been used to control this insect, with chemical control being the most used (Chirinos et al., 2004). In the last decade, some farmers have adopted more organic agronomic management practices; however, these applications are still limited. It should be noted that a large part of the SLM is, by decree, a Special Zone of Sustainable Development; for this reason, agricultural systems established there must be based on agro-ecological methods that allow sustainability. This requires a reduction in the use of agrochemicals and increased use of organic methods.

It is believed that the damage caused by C. linarosae on guava plants is influenced by the methods and techniques applied to control pests but there is no agreement on the effectiveness of organic or conventional chemical methods. This study tested the hypothesis that there is no difference in the magnitude of damage caused by the guava cottony scale on plants subjected to different control methods: organic and use of chemicals.

\section{MATERIALS AND METHODS}

This research was conducted on two farms or production units (PU): Agropecuaria Aranzazu $\left(\mathrm{PU}_{\mathrm{A}}\right.$, $8^{\circ} 48^{\prime} 27^{\prime \prime} \mathrm{N}$ and $71^{\circ} 46^{\prime} 48^{\prime \prime} \mathrm{W}$ ) and Agropecuaria El Toro

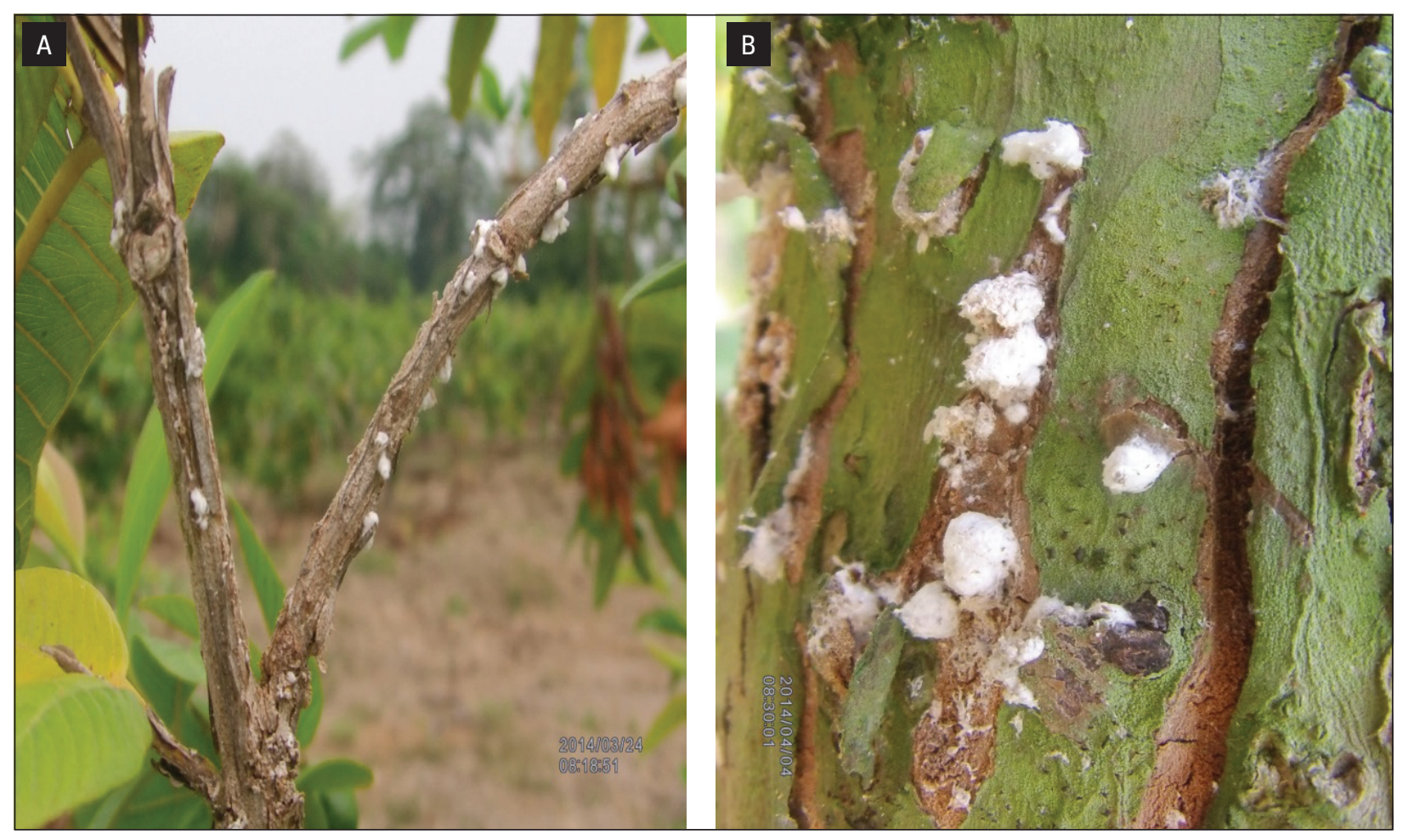

Figure 1. A. Young colony of Capulinia linarosae on a branch. B. Young colony of $C$. linarosae on a principal stem. Photos: J. Redondo-Méndez. 
$\left(\mathrm{PU}_{\mathrm{B}}, 8^{\circ} 48^{\prime} 30^{\prime \prime} \mathrm{N}\right.$ and $\left.71^{\circ} 46^{\prime} 03^{\prime \prime} \mathrm{W}\right)$, both located next to the Santa Barbara-El Vigia highway, near El Moralito, Municipality of Colon, State of Zulia, Venezuela. $\mathrm{PU}_{\mathrm{A}}$ had a guava orchard of 5 ha, and $\mathrm{PU}_{\mathrm{B}}$ had 2 ha.

The study area has an annual average rainfall of more than $2,000 \mathrm{~mm}$. The annual distribution of rainfall is bi-seasonal, with a short dry period of 3 to 4 months between December and March, and a rainy season of 8 to 9 months, between April and November. The average annual temperature is $28^{\circ} \mathrm{C}$, with monthly minimums and maximums that range between 21.4 and $34.2^{\circ} \mathrm{C}$ (Seijas, 1984). The ecological unit in the study area was tropical humid forest (Ewel et al., 1976).

Each plantation was divided into $30 \times 30$ m plots, and one of these plots was selected at random for observations in a sub-sample of 40 plants/PU; the subsample plants were also randomly selected using a table of random numbers. The damage was evaluated in (a) the entire main stem; (b) a secondary branch, (c) 20 leaves and (d) all the fruits present on the branch. The fifth main branch was selected (using the oldest branch as the first), and, on that branch, the first secondary branch was chosen. The leaves were counted starting from the apical end of the selected secondary branch.

To estimate the magnitude of damage caused by $C$. linarosae, the methodology proposed by Güerere and Quiroz (2000) was modified as follows: zero (0): no observable damages; one (1): slight damage, the surface of stems and branches with up to $20 \%$ depressions, incipient necrosis, brown lesions also present on the leaves and fruits; two (2) slight damage: the surface of stems and branches with up to $40 \%$ depressions, slight necrosis, brown lesions also present on the leaves and fruits; three (3) moderate damage, the surface of stems with generalized depressions up to $60 \%$, moderate necrosis on the leaves, branches and fruits, mainly brown to blackish lesions; four (4) minor damage: the surface of stems with generalized depressions up to $80 \%$, not very severe necrosis on the leaves, branches and fruits, mainly black lesions; and five (5) very severe damage: surface of stems with generalized depressions of up to $100 \%$, very severe necrosis on the leaves, branches and fruits: black lesions.

SPSS IBM ${ }^{\circledR}$ version 20 was used to process the data with a one-way analysis of variance. The variables included the damage level on the stem, secondary branch, leaves, and fruits, with a significant effect at 0.05 and 0.001 probability level.

\section{RESULTS}

\section{Description of the control methods of Capulinia linarosae}

In $\mathrm{PU}_{\mathrm{B}}$, the control method used organophosphates, such as clorpyrifos, that caused damage to the plant bark. The excessive application of chemical products manifested psoriasis (Fig. 2A) or burn and subsequent stem-necrosis (Fig. 2B).

On the contrary, $\mathrm{PU}_{\mathrm{A}}$ had an integrated control of C. linarosae; chemical products (i.e. profenofos: 0-4-bromo-2-clorofenil-0-etil-S-propilfosforotioato) were applied only when (following the farmer's criteria) there were "severe population outbreaks" of the insect. On the other hand, a sulfur-calcium liquid mixture was applied every $15 \mathrm{~d}$, controlling C. linarosae and promoting the establishment of green algae (Fig. 2C). Additionally, to control the insect, $\mathrm{PU}_{\mathrm{A}}$ used a product consisting of $2 \mathrm{~kg}$ of urea, $1 \mathrm{~L}$ of vinegar and $1 \mathrm{~kg}$ of detergent powder, dissolved in $200 \mathrm{~L}$ of water, that was applied every six months with a motor sprinkler. According to the farmer, this product gave satisfactory results.

\section{Description of the weed control methods}

$\mathrm{PU}_{\mathrm{B}}$ used systemic (glyphosate) and contact herbicides (paraquat and diquat). As a consequence of these applications, the soil lost its vegetative layer (Fig. 3A). When weeds reappeared, they were removed with a scythe, leaving a vegetative layer with a height of about $10 \mathrm{~cm}$.

In $\mathrm{PU}_{\mathrm{A}}$, the weed control was carried out only with a scythe, cutting at $20 \mathrm{~cm}$ or more above the ground (Fig. 3B).

\section{Description of fertilization methods}

The fertilization in $\mathrm{PU}_{\mathrm{B}}$ was done with a complete formula $(\mathrm{N}, \mathrm{P}, \mathrm{K})$, alternating it with a mix of Poliverdol ${ }^{\circledR}$ (16-16-12); foliar fertilizer, insecticides and fungicides were applied by helicopter. $\mathrm{PU}_{\mathrm{A}}$ used an organic fertilizer prepared in situ, known locally as "guarapita", applied every 3 months; it consisted of $40 \mathrm{~kg}$ of fresh cow dung, $20 \mathrm{~L}$ of whey, $20 \mathrm{~kg}$ of molasses, $4 \mathrm{~kg}$ of ash, 4 bledo plants (Amaranthus sp.) and 5 spoons of yeast; all dissolved in $200 \mathrm{~L}$ of water. 

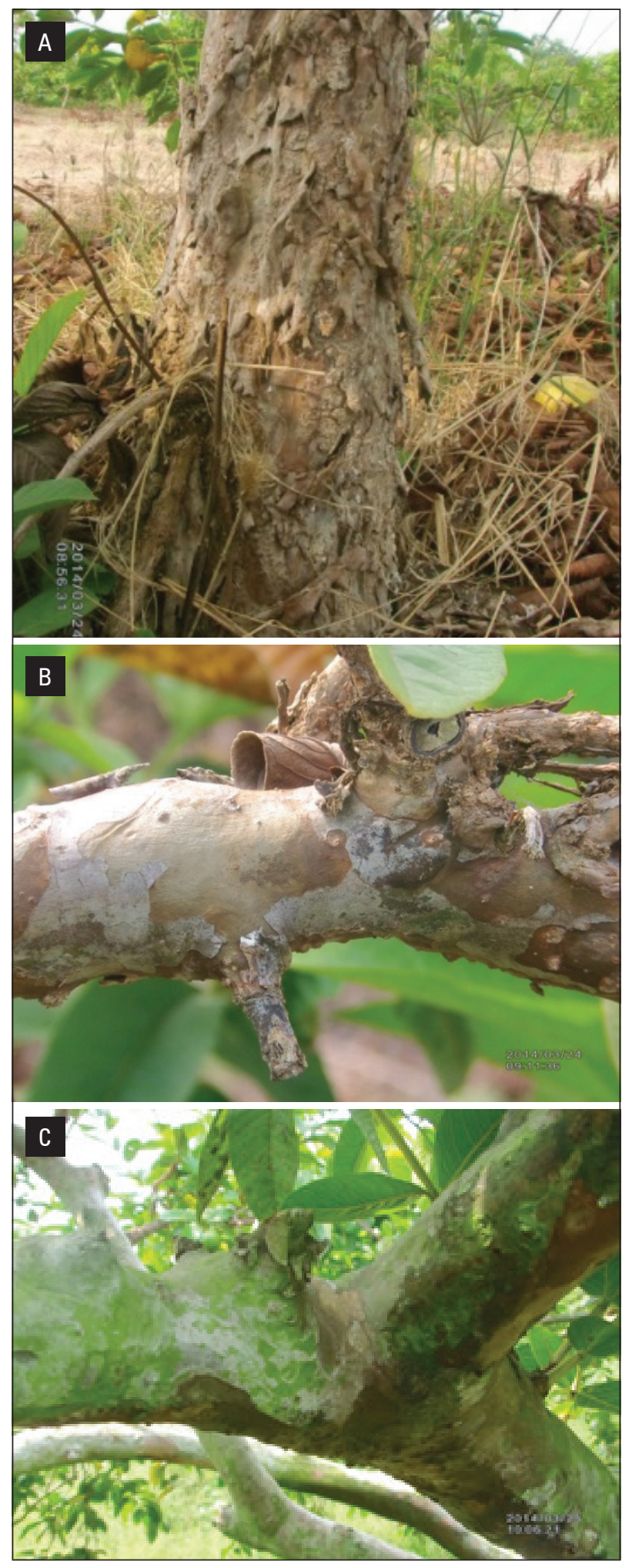

Figure 2. A. Exfoliation of the stem bark. B. Stem necrosis. C. Green algae on the stem of a plant treated with the sulfured-calcium mixture. Photos: J. Redondo-Méndez.

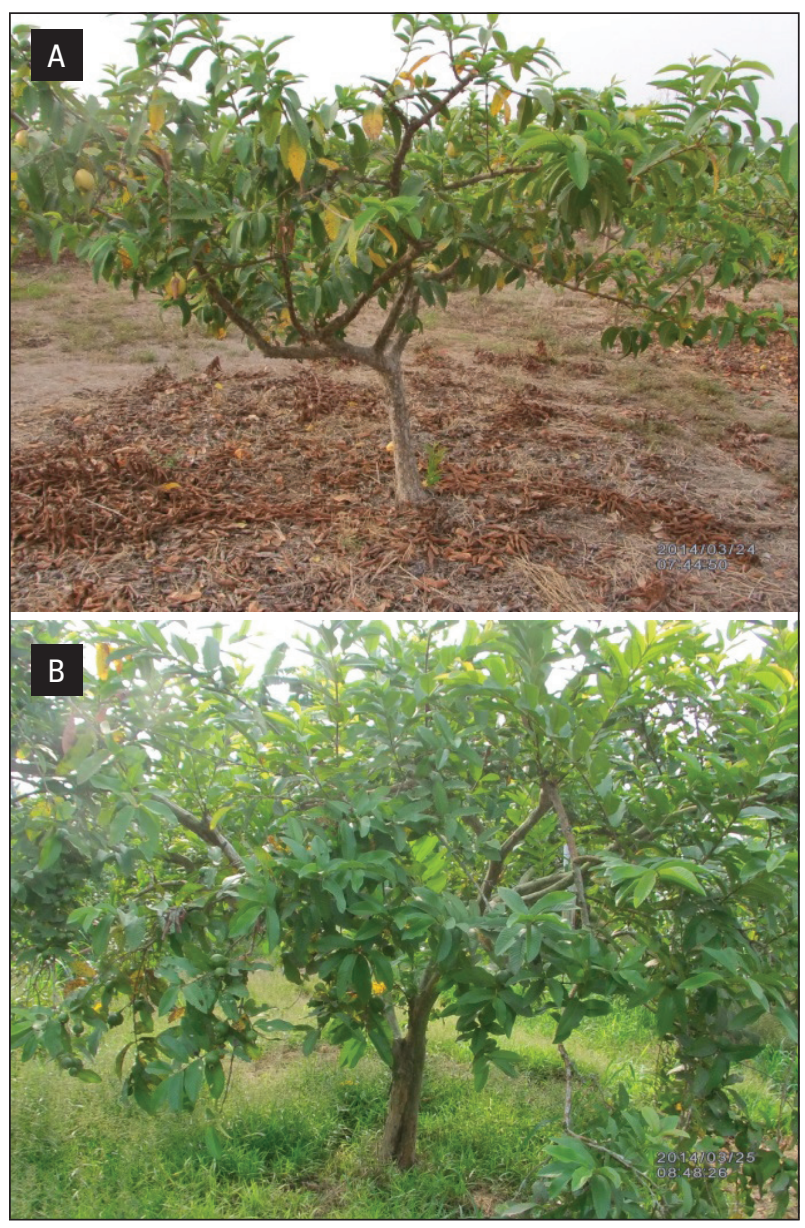

Figure 3. A. Soil without vegetative layer after weeding with Paraquat. B. Soil with $20 \mathrm{~cm}$ or more of vegetation cover after manual weed removal. Photos: J. Redondo-Méndez.

Additionally, $\mathrm{PU}_{\mathrm{A}}$ used a product consisting of $2 \mathrm{~kg}$ of urea, $1 \mathrm{~L}$ of vinegar and $1 \mathrm{~kg}$ of detergent powder, dissolved in $200 \mathrm{~L}$ of water, applied every 6 months with a motor sprinkler. According to the farmer, this product gave satisfactory results.

\section{Description of pruning methods in the guava plants}

In $\mathrm{PU}_{\mathrm{B}}$, the pruning was not frequent, so cracks in the cortex remained that facilitated the presence of the insect.

$\mathrm{PU}_{\mathrm{A}}$ used moderate pruning to limit the vertical growth of the plants. Every time the plants became sick (the branches, leaves, and fruits were necrosed), phytosanitary pruning was performed, and the pruned material was piled close to the plant. 


\section{Damage levels}

The insects caused little damage in the leaves and fruits but instead were established mainly in the most shaded parts, especially in the main and secondary stems that covered them completely. The average damage level was greater in the PU where a chemical control was applied (Fig. 4).

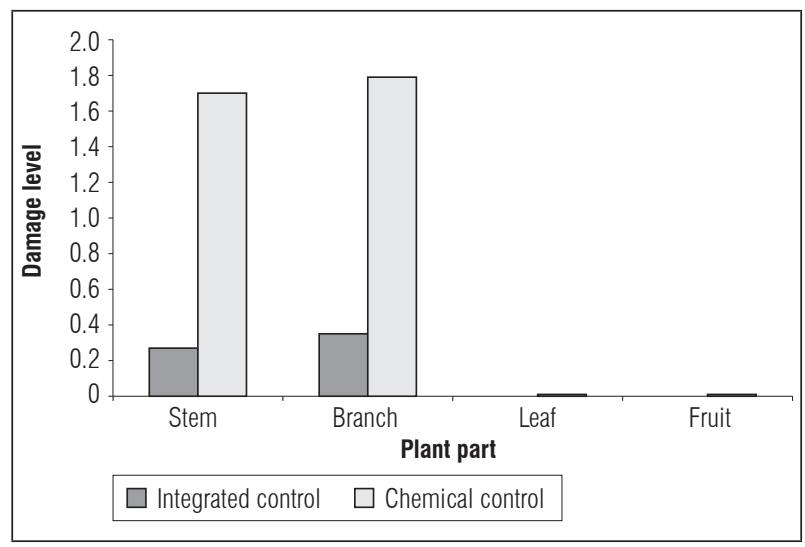

Figure 4. Damage levels on the studied farms.

Statistically significant differences were found $(P<0.0001)$ between the control methods for the stems and branches (Tab. 1) but not for the leaves or fruits $(P>0.05)$, so the hypothesis that there is no difference in the magnitude of damage estimated for the two crops was rejected.

Table 1. The exit of analysis of variance.

\begin{tabular}{|l|c|l|}
\hline \multicolumn{1}{|c|}{ Plant part } & F & Sig. \\
\hline Stem & 67.703 & $0.000^{* * *}$ \\
\hline Branch & 93.329 & $0.000^{* * *}$ \\
\hline Leaf & 1.101 & 0.296 \\
\hline Fruit & 1.101 & 0.296 \\
\hline
\end{tabular}

** significant at $P<0.001$.

\section{DISCUSSION}

In $\mathrm{PU}_{\mathrm{B}}$, the chemical methods to control C. linarosae altered the stem-bark texture and, therefore, favored the establishment and proliferation of the guava cottony scale.

Organophosphorus insecticides have a prolonged residual effect on guava leaves and stems. According to
Ettiene et al. (2010), its persistence is greater on stems than on leaves because stems are protected from direct exposure to sunlight, while, on leaves, it is volatilized and photo-degraded, which explains the scant damage caused by insects in that part of the plant. On the other hand, detailed studies have suggested that in plants with less bark exfoliation tend to occur fewer infestations (Geraud-Pouey et al., 2001b).

Chemical insecticides represent a useful alternative to control agricultural pests although their use must be minimized because of the negative effects on agrosystems, mainly as the result of their lethal impact on beneficial insects (Devine et al., 2008; Chirinos and Geraud-Pouey, 2011; Grogan, 2014) but also because of the detrimental effect on human health (Devine et al., 2008).

In many cases, farmers are unaware that there are insects that are natural predators of pests, which inhibits appropriate management decisions; they opt for the most immediate methods, such as the use of broad-spectrum insecticides. This decision can worsen the problem because these products are more expensive (Grogan, 2014). Many coccinellid beetles are recognized as natural enemies of $C$. linarosae (Romay et al., 2016), and some parasitoid wasps, such as Hymenopteran Metaphycus marensis are potential natural enemies (Chirinos and Kondo, 2019).

The application of profenofos in $\mathrm{PU}_{\mathrm{A}}$ did not seem to affect the plants but it prevented the establishment and proliferation of the insect. Moreover, the application of a sulfur-calcium liquid mixture controlled C. linarosae since it regulates the soil $\mathrm{pH}$, favors the effect of chemical or organic products, and promotes the establishment of beneficial microorganisms, such as some green algae, that, when established, cover cracks in plants, making insect establishment difficult.

The application of glyphosate (a systemic herbicide) and paraquat and diquat (contact herbicides) caused a reduction in the total disappearance of epigeous fauna and the alteration of soil organism communities, which, together, can lead to an imbalance in the agroecosystem, promoting this pests (Altieri and Nicholls, 2003; Lavelle et al., 2004).

On the other hand, the weed control method carried out in $\mathrm{PU}_{\mathrm{A}}$ allowed the farmer to maintain enough moisture in the soil during the dry season. This 
practice favored the colonization of the herbaceous stratum by natural enemies of $C$. linarosae.

Paraquat and diquat are biologically very active and highly toxic to plants and animals, especially to humans (Singh et al., 2014), moderately toxic to birds, toxic to some fungi and bacteria and increases the populations of some soil pathogens. Field observations indicate that $C$. linarosae colonizes guava plants through the soil, so this insect, upon frequent contact with this herbicide, may have developed some resistance. In addition to the fact that a lack of a vegetation layer causes the disappearance of natural enemies, this creates conditions that are favorable for increased population sizes of this pest.

The fertilization methods used in both PUs were different. Despite the application of fertilizers with a complete formula, the applications mixed with insecticides and fungicides from a helicopter in $\mathrm{PU}_{\mathrm{B}}$ did not improve the condition of the plants because the helicopter released an excessive quantity of insecticides, causing damage on the stem-bark; it can also cause physiological stress in plants and favor this insect. In contrast, the organic fertilizer used in $\mathrm{PU}_{\mathrm{A}}$ allowed the farmer to have more vigorous and more scale-resistant plants.

Some authors (for example Silva et al., 2015) have pointed out that organic fertilizers positively affect the growth of plants and minimize the advancement of insect pests and diseases. The relocation of minerals in plants can affect oviposition, growth rates, survival and reproduction of insect pests, while promoting increased populations of spiders and coleopterans, among others (Hodgson and Miller, 2010). However, García (2009) clarified that the responses of pests to organic farming methods, as compared to conventional methods, are divergent and that landscape heterogeneity is important because it benefits natural enemies.

In $\mathrm{PU}_{\mathrm{B}}$, pruning was not performed frequently, so cracks in the cortex were maintained, which facilitated the presence of $C$. linarosae. To reduce the damage caused by this insect, natural cracks and those caused by injuries must be prevented in the bark (GeraudPouey et al., 2001b). In $\mathrm{PU}_{\mathrm{A}}$, moderate pruning was carried out frequently, which reduced the availability of cracks where insects can establish and eliminated dead plant parts where pathogenic microorganisms can proliferate.
The diversification of crops and the adoption of organic practices increase the population of several natural enemies, which improve the biological control of pests (Minh and Heong, 2005; Poveda et al., 2008; Godhani et al., 2009; Mates et al., 2012; Monteiro et al., 2013; Potgieter et al., 2015).

There is abundant evidence that agronomic management exerts a marked effect on the incidence of pests (Ndolo, 2004; Mates et al., 2012; Rush et al., 2013; Veromann et al., 2013; Silva et al., 2015). For example, Oso and Falade (2010) investigated the effects of a variety of spatial arrangements on a maize crop on the incidence of the Lepidopteran Maruca vitrata and the Thysanopteran Megalurothrips sjostedti and found that the plantation pattern is a determining factor for insect infestations.

On the other hand, there are increasing indications that simplified land uses associated with heavy dependence on agrochemicals reduce environmental quality, threaten biodiversity and increase pest populations. The implementation of agronomic practices that maximize ecosystem services such as biological control of insect pests will surely increase sustainability. Therefore, the use of pesticides must be reduced and replaced with the use of innovative organic products (Garrat et al., 2011; Mates et al., 2012; Rush et al., 2013).

In short, the sustainability of an agroecosystem depends on several natural services but can also be affected by elements that occur naturally or that are man-induced, such as herbivory, which decreases productivity and increases production costs. For these reasons, the natural regulation of pests is the most important ecosystem service, maintaining a high level of biodiversity on farms (Rusch et al., 2010).

\section{CONCLUSIONS}

The magnitude of damage was greater on the farm subjected to chemical control, and agronomic management was a critical factor. Excessive pesticide use and pruning damaged the bark and favored the proliferation of the guava cottony scale in $\mathrm{PU}_{B}$. The use of a sulfur-calcium based mixture in $\mathrm{PU}_{\mathrm{A}}$ favored the effect of other products and promoted algae establishment, which covered bark crevices, impeding insect establishment. The excess agrochemicals used for weed control in $\mathrm{PU}_{\mathrm{B}}$ caused soil nudity and killed natural enemies, whereas, in $\mathrm{PU}_{\mathrm{A}}$, the grass layer was 
clipped at $20 \mathrm{~cm}$ above the soil, maintaining moisture and creating a favorable habitat for natural enemies.

Conflict of interests: The manuscript was prepared and reviewed with the participation of the authors, who declare that there exists no conflict of interest that puts at risk the validity of the presented results.

\section{BIBLIOGRAPHIC REFERENCES}

Altieri, M.A. and C.I. Nicholls. 2003. Soil fertility management and insect pests: harmonizing soil and plant health in agroecosystems. Soil Till. Res. 72, 203-211. Doi: 10.1016/S0167-1987(03)00089-8

Aular, J. and M. Casares. 2011. Consideraciones sobre la producción de frutas en Venezuela. Rev. Bras. Frutic. 33, 187-198. Doi: 10.1590/S0100-29452011000500022

Camacho, J., P. Güerere, and M. Quiroz. 2002. Insectos y ácaros del guayabo (Psidium guajaba L.) en plantaciones comerciales del estado Zulia, Venezuela. Rev. Fac. Agron. (LUZ) 19, 140-148.

Cermeli, M. and F. Geraud-Pouey. 1997. Capulinia sp., cercana a Jaboticabae Von Ihering (Hemiptera: Coccoidea, Eriococcidae) nueva plaga del guayabo en Venezuela. Agron. Trop. (1), 125-126.

Chirinos, D. and F. Geraud-Pouey. 2011. Manejo de plagas agrícolas en Venezuela. Análisis y reflexiones sobre algunos casos. Interciencia 36(3), 192-199.

Chirinos, D., F. Geraud-Pouey, L. Bastidas, M. García, and Y. Sánchez. 2007. Efecto de algunos insecticidas sobre la mota blanca de guayabo, Capulinia sp. (Hemiptera: Eriococcidae). Interciencia 8, 547-553.

Chirinos, D., F. Geraud-Pouey, and G. Romay. 2004. Desarrollo y reproducción de Capulinia sp. cercana a jaboticabae Von Ihering (Hemiptera: Eriococcidae) sobre guayabo. Entomotropica 19(3), 135-142.

Chirinos, D.T. and T. Kondo. 2019. Description and biological studies of a new species of Metaphycus Mercet, 1917 (Hymenoptera: Encyrtidae), a parasitoid of $\mathrm{Ca}$ pulinia linarosae Kondo \& Gullan. Int. J. Ins. Sci. 11, 1-9. Doi: $10.1177 / 1179543319857962$

Devine, G., D. Eza, E. Ogusuku, and M. Furlong. 2008. Uso de insecticidas: contexto y consecuencias ecológicas. Rev. Peru. Med. Exp. Salud Publica 25, 74-100.

Ettiene, G., P. García, R. Bauza, L. Sandoval, and D. Medina. 2010. Persistencia del insecticida clorpyrifos en hojas y tallos de guayabo (Psidium guajava L.). Rev. Cient. UDO Agric. 10, 36-47.

Ewel, J., A. Madriz, and J.A. Tosi. Jr. 1976. Zonas de vida de Venezuela. Memoria explicativa sobre el mapa ecológico. Ministerio de Agricultura y Cría, Fondo Nacional de Investigaciones Agropecuarias; Editorial Sucre, Caracas.
García, M. 2009. Guía técnica del cultivo de la guayaba Centro Nacional de Tecnología Agropecuaria y Forestal "Enrique Álvarez Córdoba", Ciudad Arce, Salvador.

Garrat, M.P., D.J. Wright, and S.R. Leather. 2011. The effects of farming system and fertilizers on pests and natural enemies: A synthesis of current research. Agr. Ecosyst. Env. 141, 261-270. Doi: 10.1016/j.agee.2011.03.014

Geraud-Pouey, F., D. Chirinos, R. Aguirre, Y. Bravo, and J. Quintero. 2001a. Evaluación de Metaphycus sp. (Hymenoptera: Encyrtidae) como agente de control natural de Capulinia sp. cercana a jaboticabae Von Ihering (Hemiptera: Eriococcidae). Entomotropica 16(3), 165-171.

Geraud-Pouey, F., D. Chirinos, and G. Romay. 2001b. Efecto físico de las exfoliaciones de la corteza del guayabo (Psidium guajava) sobre Capulinia sp. cercana a jaboticabae Von Ihering (Hemiptera: Eriococcidae). Entomotropica 16(1), 21-27.

Godhani, P.H., R.M. Patel, J.J. Jani, D.N. Yadav, D.M. Korat, and B.H. Patel. 2009. Impact of habitat manipulation of insect pests and their natural enemies in hybrid cotton. Karnataka J. Agr. Sci. 22, 104-107.

Grogan, K. 2014. When ignorance is not bliss: Pest control decisions involving beneficial insects. Ecol. Econ. 107, 104-113. Doi: 10.1016/j.ecolecon.2014.08.007

Güerere, P. and M. Quiroz. 2000. Escalas cualitativas del daño hecho por el ácaro plano, Brevipalpus phoenicis (Geijskes) (Tenuipalpidae), a frutos del guayabo (Psidium guajava L.). Rev. Fac. Agron. (LUZ) 17(6), 474-475.

Hodgson, C. and D. Miller. 2010. A review of the Eriococcid Genera (Hemiptera: Sternorrhinchia: Coccoidea) of South America. Zootaxa 2459(1), 1-101. Doi: 10.11646/zootaxa.2459.1.1

Kondo, T., P.J. Gullan, and L.G. Cook. 2016. A review of the genus Capulinia Signoret (Hemiptera: Coccoidea: Eriococcidae) with description of two new species. Zootaxa 4111(4), 471-491. Doi: 10.11646/zootaxa.4111.4.7

Lavelle, P., M. Blouin, J. Boyer, P. Cadet, D. Laffray, A.T. Pham-Thi, G. Reversata, W. Settle, and Y. Zuily. 2004. Plant parasite control and soil fauna diversity. Compt. Rend. Biol. 327, 629-638. Doi: 10.1016/j. crvi.2004.05.004

León, L.A., C.J. Morán, R.D. Ruiz, and W.A. Rojas. 2014. Utilización de un sistema de georeferenciación para el monitoreo fitopatológico en guayaba del Municipio Baralt, estado Zulia. p. 93. In: Resúmenes, XII Congreso Venezolano de Fruticultura. San Felipe, Venezuela.

Mates, S.G., I. Perfecto, and C. Badgley. 2012. Parasitoid wasp diversity in Apple orchards along a pest management gradient. Agri. Ecosyst. Env. 156, 82-88. Doi: 10.1016/j.agee.2012.04.016

Mendes, F., U. Muhamma, A. Newton, J. Costa, O. Ranny, and S. Willemse. 2017. Advances in guava propagation. Rev. Bras. Frutic. 39(4), 1-24. Doi: 10.1590/0100-29452017358 
Minh, L. and K.L. Heong. 2005. Effects of organic fertilizers on insect pest and diseases of rice. Omonrice 13, 26-33.

Monteiro, L.B., C. Lavigne, B. Ricci, O. Franck, J.F. Toubon, and B. Sauphanor. 2013. Predation of codling moth eggs is affected by pest management practices at orchard and landscape levels. Agric. Ecosyst. Env. 166, 86-93. Doi: 10.1016/j.agee.2011.10.012

Ndolo, D. 2004. Effects of agronomic practices on the incidence of sorghum shoot fly (Atherigona soccata) and grain yield of sorghum (Sorghum bicolor). MSc thesis. Egerton University, Egerton, UK.

Oso, A.A. and M.J. Falade. 2010. Effects of Variety and spatial arrangement on pests incidence, damage and subsequent yield of Cowpea in a Cowpea/Maize intercrop. World J. Agr. Sci. 6, 274-276.

Potgieter, L., J.H. van Vuuren, and D.E. Conlong. 2015. The role of heterogeneous agricultural landscapes in the suppression of pest species following random walk dispersal patterns. Ecol. Model. 306, 240-246. Doi: 10.1016/j.ecolmodel.2014.11.029

Poveda, K., M.A. Gómez, and E. Martínez. 2008. Diversification practices: their effect on pest regulation and production. Rev. Colomb. Entom. 34, 131-144.

Quijada, O. and J. Matheus. 1997. Factores determinantes en los precios de la guayaba en la planicie de Maracaibo. FONAIAP Divulga 57, 10-13.

Reddy, Mr. 2016. Guava cultivation information guide. In: Asia Farming, https://www.asiafarming.com/guava-cultivation; consulted: June 2018.

Romay, G., C.E. Fernández, C. Castro, and D.T. Chirinos. 2016. Diversidad de enemigos naturales asociados con Capulinia linarosae Kondo y Gullan. El Misionero del Agro 11, 78-88.
Rusch, A., M. Valantin-Morison, J. Sarthou, and J. Roger-Estrade. 2010. Biological control of insect pests in agroecosystems: effects of crop management, farming systems, and seminatural habitats at the landscape scale: a review. Adv. Agron. 109, 219-259. Doi: 10.1016/B978-0-12-385040-9.00006-2

Rush, A., M. Valantin-Morison, J.P. Sarthou, and J. Roger-Estrade. 2013. Effect of crop management and landscape context on insect pest populations and crop damage. Agric. Ecosyst. Manag. 166, 118-125. Doi: 10.1016/j.agee.2011.05.004

Seijas, A.E. 1984. Estudio faunístico preliminar de la Reserva de Fauna Silvestre de las Ciénagas de Juan Manuel Aguas Blancas y Aguas Negras Estado Zulia. Serie Informes Técnicos DGSIIA/IT/147. Ministerio del Ambiente y de los Recursos Naturales Renovables, Caracas.

Silva, R., H. Carmo, V. Vilas-Boas, D.J. Barbosa, M. Monteiro, P. Guedes de Pinho, M de L. Bastos, and F. Remião. 2015. Several transport systems contribute to the intestinal uptake of Paraquat, modulating its cytotoxic effects. Toxicol. Lett. 232, 271-283. Doi: 10.1016/j. toxlet.2014.10.015

Singh, B., J.S. Kular, H. Ram, and M.S. Mahal. 2014. Relative abundance and damage of some insect pests of wheat under different tillage practices in rice-wheat cropping in India. Crop Prot. 61, 16-22. Doi: 10.1016/j. cropro.2014.03.005

Veromann, E., M. Toome, A. Kannaste, R. Kaasik, L. Copolvici, J. Flink, G. Kovács, L. Arits, A. Luik, and U. Niinemets. 2013. Effects of nitrogen fertilization on insect pests, their parasitoids, plant diseases and volatile organic compounds in Brassica napus. Crop Prot. 43, 79-88. Doi: 10.1016/j.cropro.2012.09.001 